Economics Development Analysis Journal

\title{
Analisis Kebijakan Pemerintah dalam Meningkatan Daya Saing Industri Pakaian Jadi
}

Awinda lutfina Ratnasari ${ }^{1 凶}$, P. Eko Prasetyo ${ }^{2}$

${ }^{1} \mathrm{PT}$. Dayamitra Telekomunikasi

${ }^{2}$ Jurusan Ekonomi Pembangunan, Fakultas Ekonomi, Universitas Negeri Semarang

\begin{tabular}{|c|c|}
\hline Info Artikel & Abstrak \\
\hline $\begin{array}{l}\text { Sejarah Artikel: } \\
\text { Diterima September } \\
2016 \\
\text { Disetujui Oktober } 2016 \\
\text { Dipublikasikan } \\
\text { November } 2016\end{array}$ & $\begin{array}{l}\text { Daya saing industri pakaian jadi Kabupaten Semarang belum baik dan cenderung melemah. Tujuan dari } \\
\text { penelitian ini adalah untuk mengetahui daya saing industri pakaian jadi di Kabupaten Semarang, kebijakan } \\
\text { pemerintah terhadap daya saing industri pakaian jadi, sensitivitas industri pakaian jadi di kabupaten Semarang } \\
\text { terhadap perubahan upah, harga tarif dasar listrik, dan BBM, Kebijakan pemerintah dalam upaya meningkatkan } \\
\text { daya saing industri pakaian jadi di kabupaten Semarang. Penelitian ini menggunakan desain penelitian dengan } \\
\text { pendekatan kuantitatif. Analisis data menggunakan analisis Revealed Comparative Analysis (RCA), Policy Analysis } \\
\text { Matrix (PAM) dan analisis sensitivitas. Hasil penelitian ini menunjukan, berdasarkan nilai indeks RCA nilai daya } \\
\text { saing komparatif industri pakaian jadi Kabupaten Semarang pada tahun 2008-2012 cenderung melemah, hasil } \\
\text { analisis PAM tahun 2010-2012 daya saing keunggulan komparatif dan kompetitif memiliki nilai yang cenderung } \\
\text { melemah. Kebijakan pemerintah yang berlaku menyebabkan industri mengeluarkan biaya lebih besar dari biaya } \\
\text { imbangan untuk berproduksi. Sensitivitas pada kebijakan kenaikan upah minimum dapat menurunkan daya } \\
\text { saing, sedangkan kenaikan TDL dan BBM tidak berdampak terhadap daya saing namun dapat mengurangi } \\
\text { keuntungan. Dalam upaya meningkatan daya saing dan keuntungan, perubahan kebijakan pemerintah yang } \\
\text { berlaku harus diimbangi dengan kenaikan nilai tambah. }\end{array}$ \\
\hline
\end{tabular}

\section{Abstract}

The competitiveness of the apparel industry Semarang regency has not been good, tends to weaken. The purpose of this research was to determine the competitiveness of the apparel industry in Semarang District, government policies on the competitiveness of the apparel industry, the sensitivity of the apparel industry in Semarang regency to changes in wages, the price of the basic electricity tariff and fuel prices, government policy in improving the competitiveness of the apparel industry in the district of Semarang. The design of this research study with a quantitative approach. Analyzed using Revealed Comparative Analysis ( $R C A$ ), the Policy Analysis Matrix (PAM) and sensitivity analysis. These results indicate, RCA index value based on the comparative competitiveness of the apparel industry Semarang District in 2008-2012 tended to weaken, PAM analysis results in 2010-2012 competitiveness comparative and competitive advantages have values that tend to weaken. Prevailing government policies caused the industry to spend more than the opportunity costs of production. Sensitivity to the policy of minimum wage increases could reduce the competitiveness. While the rise in electricity and fuel prices had no impact on competitiveness but may reduce profits. In an effort to increase competitiveness and profitability, the changes in government policies that apply to be offset by the increase in value -added

(C) 2016 Universitas Negeri Semarang

J1. Letjen MT Haryono Kav 15 Tebet Barat Tebet Jakarta Selatan

DKI Jakarta, 12810

E-mail: awindalutfina@gmail.com 


\section{PENDAHULUAN}

Sektor Industri merupakan salah satu sektor yang berperan penting bagi ekonomi Indonesia terutama dalam pembangunan nasional. Menurut Mudrajad Kuncoro (2007), suatu negara akan tumbuh berkembang jika negara tersebut ditopang oleh sektor industri yang kuat, sedangkan sektor lainnya mendukung sektor industri tersebut. Sektor industri berperan sebagai sektor pemimpin (Leading Sector). Produk-produk industri selalu memiliki terms of trade yang tinggi atau lebih menguntungkan serta menciptakan nilai tambah yang lebih besar dibandingkan produk-produk sektor lain. Hal ini disebabkan karena sektor industri memiliki variasi produk yang sangat beragam dan mampu memberikan tambahan manfaat kepada pemakainya (Dumairy, 2000)

Berdasarkan data dari Badan Pusat Statistik (BPS), ekspor Jawa Tengah didominasi oleh Industri Tekstil dan Produk Tekstil (TPT), pada tahun 2010 persentase nilai ekspor TPT mencapai37,93\% dengan nilai ekspor sebesar $1.572,52$ juta US\$ dan pada tahun 2011persentase nilai ekspor TPT meningkat menjadi $39,74 \%$ dengan nilai ekspor sebesar 1.864,52juta US\$. Pada tahun 2012 persentase ekspor industri TPT turun menjadi 37,89\% dengan nilai ekspor sebesar 1.760,45 juta US\$. Berdasarkan data dari Dinas Perindustrian dan Perdagangan Jawa Tengah sumbangan terbesar dari ekspor TPT Jawa Tengah didominasi oleh ekspor pakaian jadi. Nilai ekspor pakaian jadi meningkat dari tahun ketahun. Pada tahun 2010 nilai ekspor sebesar 1.234,46 juta US\$. Pada tahun 2012 nilai ekspor terus meningkat mencapai 1.462,06 juta US\$. Hal ini menunjukan bahwa komoditi pakaian jadi merupakan dapat menjadi salah satu subsektor andalan penyumbang ekspor Jawa Tengah.

Tabel 1. Nilai Produksi Industri Pakaian Jadi Kabupaten Kudus, Kabupaten Semarang dan Kota Surakarta pada Tahun 2010-2012 (juta Rupiah)

\begin{tabular}{llll}
\hline \multirow{2}{*}{ Kota/Kabupaten } & \multicolumn{3}{c}{ Tahun } \\
\cline { 2 - 4 } & $\mathbf{2 0 1 0}$ & $\mathbf{2 0 1 1}$ & $\mathbf{2 0 1 2}$ \\
\hline Kabupaten Kudus & $2.191 .336,12$ & $2.284 .692,26$ & $2.318 .498,18$ \\
Kabupaten Semarang & $\mathbf{3 . 2 3 5 . 0 9 1 , 2 3}$ & $\mathbf{3 . 2 0 0 . 4 0 5 , 7 2}$ & $\mathbf{3 . 2 6 5 . 6 1 1 , 1 6}$ \\
Kota Surakarta & $1.983 .662,73$ & $2.101 .400,96$ & $2.119 .465,64$ \\
\hline
\end{tabular}

Sumber: Badan Pusat Statistik Jawa Tengah

Kabupaten Semarang memiliki nilai produksi pakaian jadi yang tinggi dibandingkan dengan kabupaten/kota lain seperti Kabupaten Kudus dan Kota Surakarta yang memiliki persamaan dalam sektor andalan. Nilai produksi pakaian jadi Kabupaten Semarang cenderung fluktuatif dibandingkan dengan Kabupaten Kudus dan Kota Surakarta yang terus meningkat disetiap tahunnya. Berdasarkan data dari Dinas Perindustrian dan Perdagangan Kabupaten Semarang nilai Ekspor pakaian jadi Kabupaten Semarang pada tahun 2010 sebesar 101.223.451,23 US\$, pada tahun 2011 mengalami peningkatan menjadi sebesar 118.952.913,40 US\$, di tahun 2012 mengalami penurunan menjadi sebesar 106.132.482,40 US\$. Hal ini memperlihatkan kondisi daya saing pada industri ini belum baik. Ada enam komponen dalam daya saing industry yaitu faktor kondisi, permintaan, strategi perusahaan, struktur dan persaingan, pemerintah, Peluang (Song, 2015).

Penurunan ekspor yang terjadi di Kabupaten Semarang dapat disebabkan oleh kondisi perekonomian di negara lain terutama di negara tujuan ekspor. Tujuan ekspor dengan jumlah terbesar adalah Amerika dan Eropa. Krisis ekonomi yang terjadi di Amerika dan Eropa dapat berdampak pada kinerja industri tekstil termasuk industri pakaian jadi. Selain itu, adanya kebijakan pemerintah meliputi kenaikan upah minimum tenaga kerja, kenaikan tarif dasar listrik (TDL) dan kenaikan BBM dapat berdampak pada harga input (Gustiani, 2009). Kenaikan harga input akan diikuti oleh biaya 
produksi yang tinggi. Biaya Produksi yang tinggi akan mengurangi tingkat efesiensi sehingga harga output yang kurang kompetitif (Prasetyo,2014). Disamping itu intervensi pemerintah berupa kebijakan turut mempengaruhi keunggulan kompetitif dan komparatif.

Tujuan dari penelitian ini adalah untuk mengetahui daya saing industri pakaian jadi di Kabupaten Semarang, kebijakan pemerintah terhadap industri pakaian jadi di Kabupaten Semarang, sensitivitas industri pakaian jadi di kabupaten Semarang terhadap perubahan upah, harga tarif dasar listrik, dan BBM, kebijakan pemerintah dalam upaya meningkatkan daya saing industri pakaian jadi di kabupaten Semarang.

\section{METODE PENELITIAN}

Variabel Penelitian dalam penelitian ini terdapat variabel input dan output industri pakaian jadi Kabupaten Semarang. Variabel input - output industri dalam analisis PAM dibedakan menjadi dua jenis yaitu variabel tradeable dan variabel non tradeable (variabel domestik). Variabel tradeable merupakan variabel yang diperdagangkan, dalam penelitian ini variabel tradeable yaitu pakaian jadi, bahan baku, bahan bakar, mesin dan perlengkapan, tenaga listrik dan biaya diluar bahan baku. Sebaliknya variabel non tradeable merupakan variabel yang tidak diperdagangakan. seperti tenaga kerja, kendaraan, modal dan sewa tanah dan gedung (lahan).

Penelitian ini menggunakan data sekunder. Data sekunder yang dibutuhkan diperoleh dari Badan Pusat Statistik (BPS) Provinsi Jawa Tengah meliputi,data Statistik Ekspor Jawa Tengah tahun 2010-2012. Data sekunder yang dibutuhkan diperoleh dari Badan Pusat Statistik (BPS) Kabupaten Semarang meliputi, Statistik Industri Besar dan Sedang Kabupaten Semarang Tahun 2010-1012. Data yang dibutuhkan diperoleh dari Dinas Perindustrian dan Perdagangan Kabupaten Semarang meliputi data Ekspor Seluruh Komoditas Tahun Kabupaten Semarang Tahun 2010-2012 dan data Ekspor Industri Pakaian jadi Tahun Kabupaten Semarang Tahun 2010-2012. Data yang dibutuhkan diperoleh dari Dinas Perindustrian dan Perdagangan Provinsi Jawa Tengah yaitu,data Ekspor Ekspor Seluruh Komoditas Jawa Tengah Tahun 2010-2012 dan data Ekspor Industri Pakaian jadi Jawa Tengah Tahun 2010-2012.

Metode Analisis Penelitian ini menggunakan alat analisis PAM (Policy Analysis Matrix). PAM merupakan alat analisis yang digunakan untuk mengetahui efisiensi ekonomi dan besarnya insentif atau intervensi dalam berbagai aktivitas usahatani secara keseluruhan dan sistematis. Dalam penelitian ini PAM menyusun matrik yang berisi informasi biaya, pendapatan dan keuntungan privat serta sosial industri pakaian jadi Kabupaten Semarang. Informasi biaya, pendapatan dan keuntungan privat serta sosial industri memberikan indikator daya saing industri yaitu keunggulan komparatif dan kompetitif. Selain itu analisis PAM juga dapat digunakan untuk mengetahui apakah suatu kebijakan dapat memperbaiki daya saing terhadap industrisuatu komoditi yang dihasilkan melalui penciptaan efisiensi usaha dan pertumbuhan pendapatan.

Tabel 2 dapat menghasilkan indikator profitabilitas, daya saing dan dampak kebijakan pemerintah. Dalam penelitian ini, indikator profitabilitas yang dianalisis adalah keuntungan privat dan keuntungan sosial. Indikator daya saing industri yang dianalisis adalah keunggulan komparatif dan kompetitif. Indikator kebijakan pemerintah yang diterima industri dapat dianalisis melalui Indikator kebijakan input, kebijakan output serta kebijakan input output dapat dihitung melalui informasi yang disusun dalam martik PAM. 
Tabel 2. Matriks Analisis Kebijakan (Policy Matrix Analisys/PAM)

\begin{tabular}{|c|c|c|c|c|}
\hline \multirow[b]{2}{*}{ Uraian } & \multirow[b]{2}{*}{ Penerimaan } & \multicolumn{2}{|c|}{ Biaya - biaya } & \multirow[b]{2}{*}{ Keuntungan } \\
\hline & & Input Tradable & $\begin{array}{c}\text { Faktor } \\
\text { Domestik }\end{array}$ & \\
\hline $\begin{array}{l}\text { Harga financial } \\
\text { (private price) }\end{array}$ & A & B & $\mathrm{C}$ & $\mathrm{D}$ \\
\hline Harga & & & & \\
\hline $\begin{array}{c}\text { ekonomi/Sosial } \\
\text { (social price) }\end{array}$ & $\mathrm{E}$ & $\mathrm{F}$ & G & $\mathrm{H}$ \\
\hline $\begin{array}{c}\text { Dampak Kebijakan } \\
\text { dan distorsi pasar } \\
\text { (divergences effect) }\end{array}$ & I & $\mathrm{J}$ & $\mathrm{K}$ & $\mathrm{L}$ \\
\hline
\end{tabular}

Sumber: Pearson dkk, 2005

Keterangan :

1. Keuntungan finansial, $\mathrm{D}=\mathrm{A}-(\mathrm{B}+\mathrm{C})$

2. Keuntungan ekonomi, $\mathrm{H}=\mathrm{E}-(\mathrm{F}+\mathrm{G})$

3. Rasio biaya finansial, $\mathrm{PCR}=\mathrm{C} /(\mathrm{A}-\mathrm{B})$

4. Rasio biaya sumber daya domestik, $\mathrm{DRC}=$ $\mathrm{G} /(\mathrm{E}-\mathrm{F})$

5. Koefesien proteksi nominal (NPC)

a) Pada output tradable, NPCO = A / E

b) Pada input tradable, NPCI = B / F

6. Koefesien proteksi efektif, $\mathrm{EPC}=(\mathrm{A}-\mathrm{B}) /$ $(\mathrm{E}-\mathrm{F})$

7. Koefesien profitabilitas, $\mathrm{PC}=(\mathrm{A}-\mathrm{B}+\mathrm{C}) /$ $(\mathrm{E}-\mathrm{F}+\mathrm{G})$

8. Rasio subsidi pada produsen, $\mathrm{SRP}=\mathrm{L} / \mathrm{E}$ atau $(\mathrm{D}-\mathrm{H}) / \mathrm{E}$

Inikator indikator daya saing dan dampak kebijakan pemerintah dalam tabel PAM adalah pertama, daya saing daya saing industri melalui keunggulan kompetitif dan komparatifnya. Keunggulan kompetitif didasarkan pada perhitungan keuntungan privat dan indikator Private Cost Ratio (PCR). Keunggulan Komparatif dapat dihitung melalui keuntungan sosial indikator Domestic Resource Cost Ratio
(DRCR) dilihat dari nilai Domestic Resource Cost (DRC). Kedua, Analisis kebijakan Analisis kebijakan pemerintah yang mempengaruhi industri pakaian jadi Kabupaten Semarang terdiri dari kebijakan input, kebijakan output serta kebijakan input - output. Kebijakan Output dapat dilihat dari Nominal Protection Coefficient on Output (NPCO). Kebijakan output ini berasal dari notasi penerimaan privat dan sosial (A \& E) pada tabel PAM. Kebijakan Input terdiri dari Nominal Protection Coeffisien on Tradeable Input (NPCI). Kebijakan input tersebut berasal dari notasi penerimaan privat dan sosial (B, F, C dan G) pada tabel PAM. Kebijakan input - output terdiri dari kebijakan Efective Protection Coefficient (EPC), Profitability Coefficient (PC) dan Subsidi Ratio to Producer (SRP). Kebijakan output tersebut berasal dari notasi penerimaan privat dan sosial (A, B, D, E, $\mathrm{F}$ dan $\mathrm{H}$ ) pada tabel PAM.

\section{HASIL DAN PEMBAHASAN}

Analisis Revealed Comparative Analyisis (RCA)

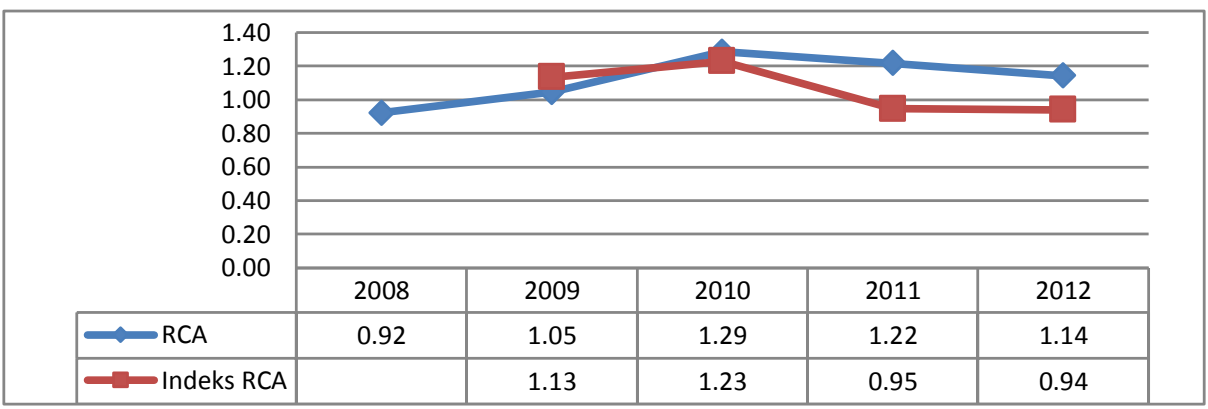

Gambar 2. Hasil Perhitungan Analisis Revealed Comparative Analysis (RCA) 
Pada Gambar 2 hasil perhitungan RCA periode tahun 2008-2012industri pakaian jadi Kabupaten Semarang memiliki daya saing (keunggulan komparatif). Setiap tahunnya industri pakaian jadi Kabupaten Semarang memiliki nilai $\mathrm{RCA}<1$ kecuali pada tahun 2008, karena di tahun tersebut nilai RCA $<1$ yaitu sebesar 0,92, artinya pada tahun 2008 tidak memiliki daya saing. Pada tahun 2009 nilai RCA naik menjadi sebesar 1,05, ditahun berikutnya yaitu tahun 2010 nilai RCA meningkat menjadi sebesar 1,29. Pada tahun 2011 nilai RCA menurun menjadi 1,22 dan terus menurun di tahun 2012 menjadi sebesar 1,14. Berdasarkan nilai indeks RCA pada Gambar 4.1, daya saing industri pakaian jadi Kabupaten Semarang pada tahun-tahun terakhir cenderung tidak mengalami peningkatan atau cenderung stabil. Dapat dilihat di tahun 2011 nilai indeks RCA $<1$ yaitu 0,95 , artinya tidak ada peningkatan. Pada tahun 2012 nilai indeks $\mathrm{RCA}<1$ yaitu 0,94 , artinya industri pakaian jadi Kabupaten Semarang tidak ada peningkatan. Selain itu nilai RCA dalam periode tersebut memiliki nilai mendekati 1 , sehingga dapat disimpulkan bahwa kinerja komoditi pakaian jadi dan daya saing industri pakaian jadi Kabupaten Semarang cenderung lemah.

Daya saing industri pakaian jadi Kabupaten Semarang cenderung lemah salah satu faktornya dapat disebabkan oleh kondisi perekonomian di negara lain terutama di negara tujuan ekspor. Faktor lainnya dapat disebabkan oleh semakin tingginya biaya produksi. Meningkatnya upah minimum, menurunnya produktivitas tenaga kerja, kenaikan bahan baku dan kenaikan tarif dasar listrik (TDL) merupakan faktor-faktor yang dapat meningkatkan biaya produksi sehingga membuat daya saing industri melemah.

\section{Analisis Daya Saing Policy Matrix Analysis (PAM)}

Tabel 3. Rekapitulasi Hasil Analisis Daya Saing Policy Matrix Analysis (PAM) Industri Pakaian Jadi Kabupaten Semarang Tahun 2010-2012

\begin{tabular}{lll}
\hline \multirow{2}{*}{ Tahun } & $\begin{array}{l}\text { Keunggulan Komparatif } \\
\text { DRC }<1\end{array}$ & $\begin{array}{l}\text { Keunggulan Kompetitif } \\
\mathrm{PCR}<1\end{array}$ \\
\hline 2010 & 0,30 & 0,31 \\
2011 & 0,42 & 0,45 \\
2012 & 0,39 & 0,42 \\
\hline
\end{tabular}

Sumber: Hasil PAM, diolah

Berdasarkan Tabel 3 nilai DRC pada tahun 2010 sebesar 0,30, pada tahun 2011 nilai DRC meningkat menjadi sebesar 0,42, sedangkan pada tahun 2012 nilai DRC menurun menjadi sebesar 0,39 . Nilai DRC dalam periode tersebut memiliki nilai $\mathrm{DRC}<1$, sehingga dapat disimpulkan bahwa meskipun fluktuatif industri pakaian jadi Kabupaten Semarang memiliki keunggulan komparatif pada periode 2010-2012

Berdasarkan Tabel 3 nilai PCR pada tahun 2010 sebesar 0,31, pada tahun 2011 nilai PCR meningkat menjadi sebesar 0,45 , sedangkan pada tahun 2012 nilai PCR menurun menjadi sebesar 0,32 . Nilai DRC dalam periode tersebut memiliki nilai $\mathrm{PCR}<1$, sehingga dapat disimpulkan bahwa meskipun fluktuatif industri pakaian jadi Kabupaten Semarang memiliki keunggulan kompetitif. Nilai PCR lebih besar dari nilai DRC berarti, industri pakaian jadi Kabupaten Semarang lebih memiliki daya saing keunggulan komparatif dari pada keunggulan kompetitif dan menunjukan bahwa kebijakan pemerintah tidak melindungi industri. 
Tabel 4. Kebijakan Pemerintah Terhadap Industri Pakaian Jadi Kabupaten Semarang Tahun 2010-2012

\begin{tabular}{lccc}
\hline \multicolumn{1}{c}{ Indikator } & $\mathbf{2 0 1 0}$ & $\mathbf{2 0 1 1}$ & $\mathbf{2 0 1 2}$ \\
\hline NPCO & 1,00 & 1,00 & 1,00 \\
NPCI & 1,005 & 1,005 & 1,0058 \\
PC & 0,970 & 0,947 & 0,950 \\
EPC & 0,995 & 0,996 & 0,997 \\
SRP & $-.0,01$ &,- 002 & $-0,02$ \\
\hline
\end{tabular}

Sumber: Hasil PAM, diolah

Analisis kebijakan pemerintah terhadap industri pakaian jadi Kabupaten Semarang terdiri dari kebijakan output, kebijakan input, dan kebijakan input-output. Berdasarkan hasil analisis kebijakan output menunjukan bahwa tidak ada kebijakan pemerintah terhadap output industri pakaian jadi Kabupaten Semarang. Berdasarkan hasil analisis kebijakan input menunjukan tidak adanya dampak kebijakan terhadap input industri pakaian jadi Kabupaten Semarang, kenyataannya memang tidak ada subsidi langsung dari pemerintah terhadap industri pakaian jadi Kabupaten Semarang. Dilihat dari nilai PC berati keuntungan yang didapat industri lebih besar jika tidak ada kebijakan kenaikan Upah dan TDL dibandingkan dengan keuntungan yang akan diterima industri jika ada kebijakan tersebut.

Dilihat dari nilai EPC, berarti kebijakan pemerintah yang berlaku tidak efektif atau tidak adanya dampak kebijakan pemerintah yang mampu memproteksi industri pakaian jadi, nilai hasil perhitungan ini konsisten dengan nilai NPCO. Dilihat dari nilai SRP menunjukan bahwa kebijakan pemerintah yang berlaku menyebabkan industri pakaian jadi Kabupaten Semarang mengeluarkan biaya produksi lebih besar dari biaya imbangan untuk berproduksi, kebijakan yang dimaksudkan adalah perubahan upah minimum tenaga kerja, TDL dan BBM.

\section{Analisis Sensitivitas Industri Pakaian Jadi Kabupaten Semarang}

Industri pakaian jadi Kabupaten Semarang rentan dengan perubahan harga input produksi dan variabel yang mempengaruhi industri pakaian jadi, sehingga analisis sensitivitas dibutuhkan dalam penelitian ini.
Hasil analisis sensitivitas dapat dilihat pada tabel 5. Simulasi kebijakan kenaikan TDL, BBM dan nilai tambah secara bersama dapat meningkatkan keuntungan, daya saing keunggulan komparatif dan keungggulan kompetitif industri pakaian jadi Kabupaten Semarang. Namun jika kenaikan upah minimum tenaga kerja saja, maka dapat mengakibatkan menurunnya keuntungan dan daya saing keunggulan kompetitif karena meningkatkan beban input industri pakaian jadi Kabupaten Semarang mengingat bahwa industri ini merupakan industri padat karya yang rentan oleh perubahan upah minimum. Subsidi mesin dapat meningkatkan keunggulan kompetitif dan meningkatkan keuntungan. Simulasi kebijkan kenaikan BBM dan TDL tidak berdampak pada daya saing industri pakaian jadi Kabupaten Semarang. Industri sudah tidak menggunakan BBM subsidi melainkan menggunakan BBM industri. Sehingga kenaikan BBM ini tidak mempengaruhi struktur biaya produksi, tetapi hanya akan berdampak pada kenaikan biaya transportasi.

Simulasi kebijakan kenaikan nilai tambah selain dapat meningkatkan keuntungan tetapi juga dapat meningkatkan daya saing keunggulan komparatif maupun keunggulan kompetitif. Kenaikan nilai tambah dapat dicapai dengan meningkatkan produksi, kualitas komoditi yang dihasilkan sehingga nilai jual lebih tinggi. Berdasarkan hasil analisis sensitivitas dapat disimpulkan apabila terjadi kenaikan input tradable maupun input non tradable jika diimbangi dengan kenaikan nilai tambah maka tidak lagi membebani industri, tetapi dapat meningkatkan daya saing keunggulan komparatif dan keunggulan kompetitif. 
Tabel 5. Hasil Analisis Sensitivitas Industri Pakaian Jadi Kabupaten Semarang

\begin{tabular}{|c|c|c|c|c|c|c|c|}
\hline \multirow{2}{*}{$\begin{array}{l}\text { Skenario } \\
\text { Kebijakan }\end{array}$} & DRC & PCR & NPCO & NPCI & PC & EPC & SRP \\
\hline & $\begin{array}{l}\text { DRC } \\
<1\end{array}$ & $\begin{array}{l}\text { PCR } \\
<1\end{array}$ & $\begin{array}{l}\text { NPCO } \\
>1\end{array}$ & $\mathrm{NPCI}<1$ & $\mathrm{PC}>0$ & $\begin{array}{l}\text { EPC } \\
>1\end{array}$ & $\mathrm{SRP}+$ \\
\hline Kondisi Normal & 0,39 & 0,42 & 1 & 1,0058 & 0,950 & 0,997 & $-0,02$ \\
\hline Subsidi Mesin 15\% & 0,39 & 0,41 & 1 & 1,0019 & 0,954 & 0,999 & $-0,02$ \\
\hline Kenaikan Upah 15\% & 0,39 & 0,48 & 1 & 1,0058 & 0,854 & 0,997 & $-0,06$ \\
\hline $\begin{array}{l}\text { Kenaikan TDL dan } \\
\text { BBM } 30 \%\end{array}$ & 0,39 & 0,42 & 1 & 1,0124 & 0,944 & 0,993 & $-0,02$ \\
\hline $\begin{array}{l}\text { Kenaikan TDL } 20 \% \text { dan } \\
\text { BBM } 30 \%\end{array}$ & 0,39 & 0,42 & 1 & 1,0102 & 0,946 & 0,994 & $-0,02$ \\
\hline $\begin{array}{l}\text { Kenaikan TDL, BBM, } \\
\text { Upah } 10 \%\end{array}$ & 0,39 & 0,46 & 1 & 1,0080 & 0,884 & 0,996 & $-0,05$ \\
\hline $\begin{array}{l}\text { Kenaikan Bahan Baku } \\
10 \%\end{array}$ & 0,41 & 0,44 & 1 & 1,0000 & 0,952 & 1,000 & $-0,02$ \\
\hline $\begin{array}{l}\text { Kenaikan Nilai Tambah } \\
10 \%\end{array}$ & 0,34 & 0,36 & 1 & 1,0058 & 0,96 & 0,997 & $-0,02$ \\
\hline $\begin{array}{l}\text { Kenaikan TDL } 20 \% \text {, } \\
\text { BBM } 30 \% \text { dan Nilai } \\
\text { Tambah } 10 \%\end{array}$ & 0,34 & 0,36 & 1 & 1,0076 & 0,959 & 0,997 & $-0,02$ \\
\hline $\begin{array}{l}\text { Kenaikan Upah } 10 \% \\
\text { dan Nilai Tambah } 15 \%\end{array}$ & 0,32 & 0,37 & 1 & 1,0058 & 0,918 & 0,997 & $-0,04$ \\
\hline $\begin{array}{l}\text { Kenaikan Upah } 10 \% \text {, } \\
\text { TDL 20\%, BBM } 30 \% \\
\text { dan Nilai Tambah } 10 \%\end{array}$ & 0,34 & 0,40 & 1 & 1,0076 & 0,908 & 0,997 & $-0,04$ \\
\hline
\end{tabular}

Sumber: Hasil PAM, diolah

Kebijakan Pemerintah dalam Upaya Peningkatan Daya Saing Industri Pakaian Jadi Kabupaten Semarang Provinsi Jawa Tengah

Dalam upaya peningkatan daya saing industri Pakaian jadi Kabupaten Semarang perlu adanya rekomendasi kebijakan yang efektif agar industri tetap efesien serta mampu meningkatkandaya saing kompetitif dan daya saing komparatif. Berdasarkan hasil analisis sensitivitas pada table 5 dapat dipilih 3 alternatif kebijakan terbaik, yaitu pertama, Pilihan kebijakan kenaikan nilai tambah sebesar 5\% dan sebesar $10 \%$ dapat meningkatkan keuntungan privat maupun keuntungan sosial serta daya saing keunggulan komparatif dan keunggulan kompetitif. Kedua, Pilihan kebijakan kenaikan upah tenaga kerja sebesar 10\% dan kenaikan nilai tambah sebesar $15 \%$ secara bersamadapat meningkatkan daya saing keunggulan komparatif dan keunggulan kompetitif, karena dengan adanya kenaikan input tradable maupun non tradable yang diimbangi dengan meningkatnya nilai tambah maka akan meningkatkan keuntungan bagi industri pakaian jadi. Kenaikan upah tenaga kerja sebesar $10 \%$ diharapkan dapat memotivasi pekerja sehingga meningkatkan produktivitas. Ketiga, Pilihan Kebijakan kenaikan upah tenaga kerja sebesar $10 \%$, TDL sebesar 20\%, BBM sebesar 30\% dan kenaikan nilai tambah sebesar $10 \%$ secara bersama dapat meningkatkan meningkatkan keuntungan privat maupun keuntungan sosial serta daya saing keunggulan komparatif dan keunggulan kompetitif.

Tidak hanya memperhatikan faktor produksinya saja, namun juga perlu adanya upaya dalam menghadapi ancaman faktor 
eksternal. Dalam menghadapi krisis yang terjadi di negara tujuan ekpsor terbesar, Kementrian Perindustrian merancang tiga langkah yaitu; Pertama, peningkatan dan mempertahankan investasi dalam negeri. Kedua, meningkatkan pola konsumsi masyarakat. Ketiga, memacu penjualan ekspor, dengan memberi stimulan bagi idustri dengan memberi tambahan insentif dalam bentuk kemudahan mendapat bahan baku, memberikan kemudahan akses pembiayaan.

\section{SIMPULAN}

Berdasarkan nilai indeks RCA daya saing komparatif industri pakaian jadi Kabupaten Semarang pada tahun 2008-2012 cenderung melemah dan berdasarkan hasil analisis PAM industri pakaian jadi Kabupaten Semarang pada tahun 2010-2012 memiliki daya saing keunggulan komparatif dan kompetitif cenderung melemah. Kebijakan pemerintah berkaitan dengan input-output tidak efektif memproteksi industri pakaian jadi Kabupaten Semarang dan kebijakan pemerintah yang berlaku menyebabkan industri pakaian jadi Kabupaten Semarang mengeluarkan biaya lebih besar dari biaya imbangan untuk berproduksi. Sensitivitas pada kebijakan kenaikan upah minimum dapat menurunkan daya saing, sedangkan kenaikan TDL dan BBM tidak berdampak terhadap daya saing namun dapat mengurangi keuntungan. Dalam upaya peningkatan daya saing dan keuntungan industri pakaian jadi Kabupaten Semarang, kebijakan pemerintah meliputi kenaikan upah minimum tenaga kerja, kenaikan tarif dasar listrik (TDL) dan kenaikan BBM harus diimbangi dengan kenaikan nilai tambah.

Berdasarkan kesimpulan dari hasil penelitian dan pembahasan maka saran dalam penelitian ini adalahnaya saing industri pakaian jadi perlu ditingkatkan dengan adanya pengembangan pengelolaan biaya produksi agar lebih efesiensi dan industri pakaian jadi Kabupaten Semarang tidak hanya mampu bersaing tetapi juga memiliki daya saing yang meningkat. Pemerintah perlu mengkaji kembali kebijakan yang dapat menurunkan daya saing dan keuntungan industri pakaian jadi Kabupaten Semarang dan menerapkan alternatif atau tambahan kebijakan agar mampu memproteksi industri pakaian jadi Kabupaten Semarang. Pemerintah sebagai otoritas penentu kebijakan penting untuk memperhatikan perubahan variabel yang memberikan dampak pada kenaikan atau peningkatan daya saing industri pakaian jadi seperti subsidi mesin, perubahan upah minimum tenaga kerja, perubahan tarif dasar listrik, perubahan BBM. Dalam upaya peningkatan daya saing industri pakaian jadi Kabupaten Semarang pemerintah harus dapat menentukan kebijakan yang efektif agar industri tetap efesien serta mampu meningkatkan nilai tambah, daya saing kompetitif maupun daya saing komparatif.

\section{DAFTAR PUSTAKA}

Badan Pusat Statistik Provinsi Jawa Tengah. Berbagai Tahun Statistik Ekspor Jawa Tengah. Semarang: Badan Pusat Statistik Provinsi Jawa Tengah.

Badan Pusat Statistik Provinsi Jawa Tengah. Berbagai Tahun Statistik Industri Sedang dan Besar Jawa Tengah. Semarang: Badan Pusat Statistik Provinsi Jawa Tengah.

Dumairy. 2000. Perekonomian Indonesia. Cetakan Keempat. Jakarta: Erlangga.

Gustiani, Dewi. 2009. Analisis Keunggulan Komparatif dan Kompetitif Kain Tenun Sutera Produksi Kabupaten Garut (Studi Kasus pada Perusahaan PT. Aman Sahuri di Kabupaten Garut Provinsi Jawa Barat). Skripsi. Fakultas Ilmu Ekonomi. Institut Pertanian Bogor.

Kementrian Perindustrian. 2015. Industri Tekstil Dan Alas Kaki Ekspor Jadi Peluang Di Tengah Kondisi Stagnan, Diakses Tanggal 30 Mei 2016,Www.Kemenperin.Go.Id/Artikel/12126 /Industri-Tekstil-Dan-Alas-Kaki-Ekspor-JadiPeluang-Di-Tengah-Kondisi-Stagnan.

Kuncoro, Mudrajad. 2007. Ekonomika Industri Indonesia Menuju Negara Industri Baru 2031. Yogyakarta : ANDI.

Pearson, P., C. Gostch dan S. Bahri. 2005. Aplikasi Policy Analysis Matrix pada Pertanian di Indonesia. Jakarta: Yayasan Obor.

Prasetyo, P. Eko. 2014. Laporan Penelitian MP3I Dampak Kebijakan Ekonomi Terhadap Kinerja Industri Tekstil dan Produk Tekstil di 
Jawa Tengah Dalam Meninggkatkan Kapasitas SDM dan Daya Saing. Laporan Akhir Tahunan. Semarang: Universitas Negeri Semarang.

Rendleman, C. $\quad 2015$. Wine Industry Competitiveness: A survey of the Shawnee Hills American Viticultural Area. Wine Economics and Policy, 5(1), pp. 4-13.

Song, Zongyu, Dongxiao Niu, Xinli Xiao. 2015. Focus on the current competitiveness of coal industry in China: Has the depression time gone?. Resources Policy, 51, pp.172-182.

Zhao, Zhen-Yu, et al. 2016. Competitiveness assessment of the biomass power generation industry in China: A five forces model study. Renewable Energy, 89, pp.144-153. 